\title{
R\&D SPILLOVERS, INNOVATION AND MARKET VALUE: EVIDENCE OF ABSORPTIVE CAPACITY IN THE GENERATION OF CLEAN TECHNOLOGIES
}

\author{
LEONARDO ANDRADE ROCHA \\ Departamento de Ciencias Humanas, UNIVERSIDADE FEDERAL RURAL DO SEMI-ÁRIDO, BRASIL. E- \\ mail: leonardoandrocha@yahoo.com.br \\ PATRÍCIA VERÓNICA PINHEIRO SALES LIMA \\ Departamento de Economia Agrícola, UNIVERSIDADE FEDERAL DO CEARÁ, BRASIL. E-mail: \\ patricialima@ufc.br \\ AHMAD SAEED KHAN \\ Departamento de Economía Agrícola, UNIVERSIDADE FEDERAL DO CEARÁ, BRASIL. E-mail: saeed@ufc.br \\ ELIANE PINHEIRO DE SOUSA \\ Departamento de Economia, UNIVERSIDADE REGIONAL DO CARIRI, BRASIL \\ E-mail: pinheiroeliane@hotmail.com
}

\section{ABSTRACT}

The present study analyzes how efforts in innovation contribute to the market value (Tobin's Q) of firms that generate clean technologies. In an alternative perspective, the results point out that $R \& D$ investments contribute in a heterogeneous way in value, where firms located in the higher or nearer technological frontier show a greater return on the use of investments. In this case, an absorptive capacity effect demonstrates that market value is precisely more sensitive to R\&D investments for "frontier's firms". This suggests that the absorptive capacity effect is sensitive to proximity fluctuations with the frontier.

Keywords: R\&D, Innovation, absorptive capacity.

Externalidades del I\&D, innovación y mercado de valores: evidencia de capacidad de absorción en la generación de tecnologías limpias.

\section{RESUMEN}

El presente estudio analiza cómo los esfuerzos en innovación contribuyen al valor de mercado (Q de Tobin) de las empresas que generan tecnologías limpias. En una perspectiva alternativa, los resultados apuntan que las inversiones en I\&D contribuyen de forma heterogénea en el valor, donde firmas situadas en la distribución superior o más próximas a la frontera tecnológica presentan un mayor retorno en el uso de las inversiones. En este caso, un efecto-capacidad de absorción demuestra que el valor de mercado es precisamente más sensible a las inversiones en I\&D para las "firmas de la frontera". Esto sugiere que el efecto-capacidad de absorción es sensible a las fluctuaciones de proximidad con la frontera.

Palabras clave: I\&D, Innovación, capacidad de absorción.

Clasificación JEL: O30, O32, Q55 


\section{INTRODUCTION}

The center of the current debate on issues related to the environment is the organization of political arrangements aiming to achieve balanced intervention across the world. The intention is to determine how firms' research investment may affect their performance and how this impact can be differentiated between economies. This heterogeneous pattern reflects how firms respond to incentives and how this response influences the economic results between nations (Acemoglu et al. 2012, 2016). Thus, when dealing with the importance of clean technologies and green innovations, we seek to understand how the different results are associated with firms' ability to absorb the knowledge generated in the environment in which they operate (Aghion and Jaravel 2015). This approximates an important concept in the theory of innovation, called "absorptive capacity."

Since the contributions of Cohen and Levinthal (1989) on the dual role of the R\&D performance of firms, many empirical studies have sought to quantify the effect of absorptive capacity on innovation efforts (Cockburn and Henderson 1998; Yencken and Gillin 2003; Arbussà and Coenders 2007; Muscio 2007; Gluch, Gustafsson, and Thuvander 2009). However, the evaluation of firms' performance depends on the definition. One important way to analyze the performance of the firm is to use its market value, an approach that has most commonly been used in studies of this nature, corresponding to the form pioneered by Griliches (1981).

The proposed treatment following the market value of the firm can be defined as a portfolio of tangible and intangible assets. Important research in this area has sought to measure this relationship, among which the studies by Cockburn and Griliches (1988), Hall (1993), Hall (2000), Bloom and Reenen (2002), Hall, Jaffe, and Trajtenberg (2005), Coad and Rao (2006), Hall and Oriani (2006), and Coad $(2008,2011)$ can be highlighted. Of these studies, only Coad and Rao (2006) and Coad (2008, 2011) pointed out how the market value of firms may be associated with a heterogeneous effect of investments in R\&D, so that such an "effect" is associated with the concept of the "technological proximity to the frontier," like the contributions of Aghion and Howitt (1998).

Based on these contributions, this research aim at contributing to the environmental literature, since the approach to absorptive capacity becomes singular in this context. The potential effects of policy on research subsidies may spread through different incentives among firms, making the technology transfer process not as simple as is sometimes recommended. In addition, firms that operate in less developed economies depend on important structural conditions that make their absorptive capacity even more appropriate for the achievement of specific investments, such as R\&D. As Aghion and Jaravel (2015, p.538) reported:

\footnotetext{
In fact, less developed nations need to make a number of foundational investments in their own technological capabilities in order to subsequently be able to adopt the green technologies developed in the "North" and adapt them to their particular settings. Whether investments in green innovation in the "North" will strengthen the incentives of less developed nations sufficiently to lead them to invest in the required absorptive capacity is an open empirical question.
}

To capture the heterogeneous effect in the sample, the quantile regression technique is an important approach. Quantile regression analysis allows a more detailed understanding of the relationships between variables that are not properly handled in conventional regressions, especially when dealing with micro-level firms. Based on recent advances, the estimator introduced by Parente and Silva (2016), which is used in this research, enables more efficient estimates than the traditional estimator of Koenker and Basset (1978). The results show that firms located in the upper tail of the distribution obtain better results from $R \& D$ in generating value.

\section{THEORETICAL MODEL}

The literature on the relationship between market value and investment in $R \& D$ has handled the stock of firms' value like a basket consisting of tangible and intangible assets (Griliches, 1981; Hall, 2002; Hall, Jaffe, and Trajtenberg 2005; Hall and Oriani 2006; Hall et al. 2015). In this case, the market value of a company at a particular time can be represented as a function of its tangible and intangible assets: 


$$
V_{i t}=V\left(A_{i t}, K_{i t}\right) \leftrightarrow V_{i t}=q_{t}\left(A_{i t}+\gamma K_{i t}\right)^{\sigma}
$$

Equation (1) shows that the market value of a company can be expressed as the weighted sum of its assets. In the equation, "V" represents the market value of the firm, "A" the book value of tangible assets, and " $K$ " the stock of technological capital (intangible assets) associated with firm "i" at time "t."

The parameters reflect important characteristics of the firm and the market in which it operates; in addition, " $q_{t}$ " is the average ratio of the market value associated with the total assets of the firm. However, the parameter " $\sigma$ " is the coefficient of elasticity of the total assets in the company's value. Regarding methodological issues, in the literature with the particular case of " $\sigma=1$ " in this situation, " $\gamma$ " is interpreted as the "shadow value" or the cost of the technological capital opportunity for the tangible assets of the firm (Toivanen, Stoneman, and Bosworth 2002; Hall and Oriani 2006). Following Hall (2002), Hall, Jaffe, and Trajtenberg (2005), and Hall and Oriani (2006), equation (1) can be rearranged as follows:

$$
\log \left(\frac{V_{i t}}{A_{i t}}\right)=\log \left(q_{t}\right)+\log \left(1+\gamma \frac{K_{i t}}{A_{i t}}\right)
$$

According to the authors, equation (2) can be estimated by ordinary least squares, taking the condition of linear approximation as " $\log (1+x) \approx x$ ", so $\log \left(\frac{V_{i t}}{A_{i t}}\right)=\log \left(q_{t}\right)+\gamma \frac{K_{i t}}{A_{i t}}$. The problem of this specification to be estimated is establishing that the "shadow price" of technological capital on assets $(\gamma)$ is constant between the firms of the sample. This hypothesis is implausible, based on the literature on hedonic pricing models, following the contributions of Lancaster (1966) on consumer theory and subsequently Rosen (1974), who adapted the product pricing models. Thus, firms at different stages of technological development absorb knowledge in heterogeneous ways, which leads us to question this assumption of uniformity (Coad and Rao 2006; Coad 2008, 2011).

According to Cohen and Levinthal (1989, p.569), firms assimilate knowledge in the environment in which they operate and increase the return on investments in research through their absorptive capacity ("learning" or "absorptive" capacity). Thus, incentives to learn influence spending on R\&D to the extent that such "incentives" are shaped by the amount of knowledge and the ease of absorbing it. Recent surveys have shown relationships between the absorptive capacity and the proximity to the technological frontier (Griffith, Redding, and Van Reenen 2003, 2004; Aghion and Jaravel 2015), given that a firm's position in relation to its frontier conditions important incentives for innovation (Acemoglu, Aghion, and Zilibotti 2006; Amable, Demmou, and Ledezma 2010; Hölzl and Janger 2014; Ding, Sun, and Jiang 2016).

Through the absorptive capacity effect of Cohen and Levinthal (1989), the "shadow price" is conditioned by the degree of proximity to the frontier $\left(a_{i t}\right)$ on which firms are located $\left(\gamma=\gamma\left(a_{i t}\right)\right)$, raising (or reducing) the opportunity costs of the research due to fluctuations in the proximity to the frontier.

\section{EMPIRICAL METHODOLOGY}

\subsection{Sample definition and data source}

The data used in this study were drawn from an important source of data: the Capital IQ platform of Standard \& Poor's (S\&P). The S\&P Capital IQ platform is one of the most important sources of financial information, bringing together financial data from over 1 million companies worldwide. The biggest advantage of this platform is the amplitude of the data by countries and sectors, and it addresses major financial indicators of the companies, allowing a more detailed analysis of their strategy.

The run consisted of the following filters:

(i) Active firms in the world with legal origin by country and defined market value (publicly traded companies);

(ii) Firms classified according to the international credit rating industry classification; 
(iii) Selection of firms with the 1-digit "SIC Codes" corresponding to 10 sectors;

(iv) Selection of financial variables in the time period between 2006 and 2015 (10 years);

(v) Companies that invest directly or indirectly in businesses associated with sustainable technologies and "clean" technologies, involving the following keywords: "solar"; "fuel cell"; "thin film"; "wind turbine"; "renewable energy"; "photovoltaic"; "geothermal"; "alternative energy"; "clean tech"; "clean technology"; "green technology"; "nuclear power"; "smart grid"; "biomass"; "sustainable"; "sustainability"; "waste minimization"; "biodiesel"; "water reuse"; "wastewater reuse"; "ozone-based"; and "ozone solutions";

The final result was a sample of 10,729 firms distributed between 50 countries, corresponding to a panel containing 107,290 observations.

\subsection{Selection of the variables}

To measure the value of the company, the Tobin's Q of the companies was adopted, which was obtained through the ratio between the market capitalization and the financial assets. The importance of this variable is the fact that it expresses the future earnings value of companies as a result of "appropriate" behavior of the firm, being reflected in the stock market. Thus, the performance of future expectations is presented, in part, on the current trajectory of the firm's shares, which may be included in its market value (and hence the Tobin-Q) (Coad 2011).

Following Griliches (1981), Griliches and Mairesse (1984), Pakes and Griliches (1984), Hall (1993, 2000), Hall (2002), Hall, Jaffe, and Trajtenberg (2005), Coad (2006, 2008, 2011), and Hall and Oriani (2006), to measure innovation efforts, firms' investments in R\&D and the earning portion of their longterm strategy of firms were employed.

As control variables for the model, investments in short-term and capital goods were properly employed. According to Gupta, Banerjee, and Onur (2017), the control variables help to examine the influences of other factors that potentially affect a company's value and to minimize the potential endogeneity costs to the model. Following these authors, investments in capital goods have an important influence on the value of firms to the extent that the machinery acquired complements the human capital involved in the research activities. Therefore, capex investment was added to the model to control the relationship between $R \& D$ and value.

Other research has suggested that short-term financial pressures can significantly affect the management of technology. This follows especially from the capital market pressures in the evaluation of short-term performance associated with the performance of managers in firms. Thus, the analysis of firms' performance through measures of value, captured in the stock market, is relatively influenced by such strategies and by shareholders of companies (Demirag 1996; Gupta, Banerjee, and Onur 2017).

To describe better the variables involved and their references in studies related to the topic, Table 1 presents a description including the name, definition, and reference research related to the theme, which helped in the selection. 
EXTERNALIDADES DEL I\&D, INNOVACIÓN Y MERCADO DE VALORES: EVIDENCIA DE CAPACIDAD DE ABSORCIÓN EN LA GENERACIÓN DE TECNOLOGÍAS LIMPIAS.

Table 1

Variable definitions

\begin{tabular}{|c|c|c|}
\hline Variables & Definition & Applied Research \\
\hline R\&D & $\begin{array}{l}\text { Investments applied in research activities, it may occur } \\
\text { internally in companies or externally, by universities and } \\
\text { research institutes. These investments represent the financial } \\
\text { effort of the firm to finance: development of new products, } \\
\text { technical innovations, development of production processes } \\
\text { to the existing products update or service line. }\end{array}$ & $\begin{array}{l}\text { Hall (2002), Hall, Jaffe and Trajtenberg } \\
\text { (2005), Hall, Mairesse and Mohnen } \\
\text { (2010), Bogliacino and Cordona (2010), } \\
\text { Hall, Lotti and Mairesse (2013), } \\
\text { Montresor and Vezzani (2015), Kancs } \\
\text { and Siliverstovs (2016) and Castellani et } \\
\text { al. (2017) }\end{array}$ \\
\hline mkt_cap & Market capitalization value. & $\begin{array}{l}\text { Hall (2002), Dias (2013) and Hall, Jaffé } \\
\text { and Trajtenberg (2005) }\end{array}$ \\
\hline capex & $\begin{array}{l}\text { Investments made for the purpose of acquiring or updating } \\
\text { physical assets such as equipment, properties and industrial } \\
\text { plans. }\end{array}$ & $\begin{array}{l}\text { Hall, Lotti and Mairesse }(2008 ; 2013) \\
\text { and Hall, Mairesse and Mohnen }(2010) \text {, } \\
\text { Gupta, Banerjee and Onur (2017) }\end{array}$ \\
\hline asset & Total assets of the companies & $\begin{array}{l}\text { Hall (2002) and Hall, Lotti and Mairesse } \\
(2008 ; 2013)\end{array}$ \\
\hline Q-Tobin & Ratio on the market capitalization and total assets. & $\begin{array}{l}\text { Hall (2002), Hall, Jaffe and Trajtenberg } \\
\text { (2005), Coad (2008; 2011), Gupta, } \\
\text { Banerjee and Onur (2017) and Hall, } \\
\text { Jaffe and Trajtenberg (2005) }\end{array}$ \\
\hline st_inv & $\begin{array}{l}\text { Short-term investments represent investments that are } \\
\text { relatively liquid, that is, for the purpose of maintaining the } \\
\text { firm's activities for a period exceeding } 3 \text { months and less than } \\
\text { one year. }\end{array}$ & $\begin{array}{l}\text { Bourke and Roper (2017) and Cremers, } \\
\text { Pareek and Sautner (2017) }\end{array}$ \\
\hline
\end{tabular}

\subsection{Estimation Method}

This study employs the concept of "distance from the frontier" presented by Coad and Rao (2006) and Coad $(2008,2011)$ through the quantile regression technique. This technique, pioneered by Koenker and Basset (1978) and subsequently advanced in the studies by Koenker and Hallock (2001) and Koenker $(2004,2005)$, consists of a prominent breakthrough in the linear regression approach. The usual technical focus of their analysis is on the average of the conditional distribution of the dependent variable. Such an approach is not appropriate, especially in a micro-level firm. In this case, the sample outliers may represent a major problem in estimation, causing a persistent bias in the parameters even for large samples. The technique quantile provides a "picture" of the precise relationship between the variables to incorporate an analysis according to different points of the conditional distribution. Thus, the regression obtained by this technique captures the influence of the component "distance to the frontier," which directly affects the model parameters.

The quantile regression model can be described as

$$
y_{i t}=x_{i t}^{\prime} \beta(\theta)+\varepsilon_{i t}(\theta) \therefore x_{i t}^{\prime} \beta(\theta)=Q_{\theta}\left(y_{i t} \mid x_{i t}\right)
$$

where " $y$ " is the $\log ($ Tobin-Q), " $\mathrm{x}$ " the regressor vector, " $\beta$ " the vector of impact regressor parameters to be estimated, and " $\varepsilon_{i t}$ " the model of residual vector. The function $Q_{\theta}\left(y_{i t} \mid x_{i t}\right)$ denotes the ith-quantile $(0<\theta<1)$ conditional on the distribution of "y." The model parameters are obtained through the solution to the problem:

$$
\min _{\beta} \frac{1}{n}\left\{\sum_{i, t: y_{i t} \geq x_{i t}^{\prime} \beta}^{n} \theta\left|y_{i t}-x_{i t}^{\prime} \beta\right|+\sum_{i, t: y_{i t}<x_{i t}^{\prime} \beta}^{n}(1-\theta)\left|y_{i t}-x_{i t}^{\prime} \beta\right|\right\}=\min \frac{1}{n}\left\{\sum_{i, t: 1}^{n} \rho_{\theta}\left(\varepsilon_{\theta i t}\right)\right\}
$$

where the function $\rho_{\theta}($.$) is known in the literature as the "check function" and is defined as:$ 


$$
\rho_{\theta}\left(\varepsilon_{\theta i t}\right)= \begin{cases}\theta \varepsilon_{i t}, & \text { se } \varepsilon_{i t} \geq 0 \\ (1-\theta) \varepsilon_{i t}, & \text { se } \varepsilon_{i t}<0\end{cases}
$$

The econometric equation is solved by linear programming methods. The specified quantile $(0<$ $\theta<1$ ) in a particular case of " $\theta=1$ " is the total of the conditional distribution of the dependent variable. Thus, the parameters to be estimated will measure different impacts depending on the position in the conditional distribution (Koenker 2005).

\subsection{Quantile regression equation}

Following the literature presented, the estimated equation consists of:

$$
\log \left(Q_{i t}\right)=q_{0}+\gamma_{1}(\theta)\left(\frac{R \& D_{i t}}{\text { Asset }_{i t}}\right)+\gamma_{2}(\theta)\left(\frac{\text { Capex }_{i t}}{\text { Asset }_{i t}}\right)+\gamma_{3}(\theta)\left(\frac{\text { ST_inv }_{i t}}{\text { Asset }_{i t}}\right)+\varepsilon_{i t}(\theta)
$$

As the hypothesis of the research, the "shadow value" $(\gamma(\theta))$ caught in different quantiles $(\theta)$ reflects heterogeneous opportunity costs due to fluctuations in the proximity to the frontier. In this case, different points of the conditional distribution of the market value capture such fluctuations, reflecting different values of the conditional quantile (Coad and Rao 2006; Coad 2011).

\subsection{Robustness of the quantile technique}

Although the quantile regression approach provides a breakthrough data analysis, some limitations need to be addressed properly to achieve accuracy gains for the model. Among the highlights, the nature of the longitudinal data sample represents a great advantage from the standpoint of "size" but is limiting in other ways.

Recently, Koenker (2004), Harding and Lamarche (2009), Lamarche (2010), Canay (2011), Galvao (2011), and Rosen (2012) presented the technical limitations of panel data samples. This difficulty, in part, derives from the treatment of "fixed effects," which does not depend on the specified quantile, since it depicts specific features of the observations. In this case, the standard technique is not applicable due to the limitation in controlling this effect over different quantiles (Koenker 2004; Canay 2011). This limiting factor increases especially when we are dealing with short panels, in which the cross-section becomes considerably higher in relation to the temporal cut, since we cannot directly estimate the fixed effects without incurring increasing costs in the reduction of degrees of freedom and in the "incidental parameters problem" (Hahn and Newey 2004; Bester and Hansen 2016).

To overcome such problems, the vector of fixed effects " $\mu \mathrm{i}$ " was replaced by the control vectors at the sectoral level " $9 \mathrm{~s}$," time " $\tau \mathrm{t}$," and the country level " $\varphi \mathrm{j}$," following similarities to the estimator of fixed-grouped effects of Bester and Hansen (2016). Thus, the measurement error was decomposed as follows: $\varepsilon i t=\vartheta s+\tau t+\varphi j+\omega i t^{1}$.

Finally, the efficiency of the estimates depends on a technique developed by Efron (1978) called bootstrapping. However, the bootstrapping technique is not fully valid in some situations.

Unlike Coad and Rao (2006) and Coad $(2008,2011)$, in many applications in regression analysis, the estimation is performed using samples from microdata, which in turn are obtained from various groups or "clusters," assuming that the observations of different groups are conditionally independent. However, such assumptions are sometimes not supported by the reality of the data, of which the validity

\footnotetext{
${ }^{1}$ In the decomposition of the error, the fixed effects were grouped in the sector, temporal and country dimensions. In the quantum approach, the treatment of fixed effect at the individual level is not an easy task. Canay (2011) suggests the exclusion of the fixed effect treated from the difference between the dependent variable and the fixed effect $\left(Y-a_{i}\right)$, estimating the regression from the modified variable. However, this artifice has a limiting factor, which depends on relatively short panels $(\mathrm{N}>\mathrm{T})$, since approximations that take $\mathrm{T}$ to infinity can result in biased and inconsistent estimates. Moreover, observations with great value in the modified dependent variable are potentially concentrated in the lower part of the Y distribution, implying a censorship of the residuals. In addition, the parameters estimated in the adjusted model can not be interpreted in the same way as in the regression obtained by the standard estimator of Koenker and Basset (1978). Considering the potential cost / benefit among the techniques, we chose the grouping of fixed effects, following the standard literature on this theme, such as Coad (2011).
} 
of the inference procedures depends on the availability of a consistent estimator of the covariance matrix when correlation in the groups or clusters is allowed (Parente and Santos Silva 2016; Hagemann 2017).

The present research adopts Parente and Silva's (2016) estimator as an alternative and efficient approach to quantile regression analysis, called the "quantile regression estimator with robust and clustered standard errors." To define the clusters in the model, the sector-level dimension was adopted, adjusting the groups from the sectors presented at the SIC Codes level.

In this case, the results presented are more efficient than those of the standard quantile regression technique proposed by Koenker and Basset (1978) and the empirical results of Coad and Rao (2006) and Coad $(2008,2011)$.

\section{ANALYSIS OF THE RESULTS}

\subsection{Descriptive sample statistics}

According to the data in Table 2, the largest proportion of firms is from the USA and Canada (approximately $48 \%$ of the total). Secondly, approximately one-third of the sample is from the developed markets of Europe. The two regions together account for almost $80 \%$ of all firms. The Asia and Pacific market comprises approximately $15 \%$ (including developed and emerging markets). The smallest proportion of firms is found in emerging markets in Europe, Africa and the Middle East, and Latin America and the Caribbean (together they represent almost $5 \%$ of the sample).

Table 1

Distribution of firms per geographic region.

\begin{tabular}{l|c|c|c}
\hline Geographic location & $\begin{array}{c}\text { Frequenc } \\
\mathbf{y}\end{array}$ & $\begin{array}{c}\text { Relative frequency } \\
\mathbf{( \% )}\end{array}$ & $\begin{array}{c}\text { Cumulative frequency } \\
(\mathbf{\%})\end{array}$ \\
\hline Asia / Pacific; Asia / Pacific Developed & 671 & 6,25 & 6,25 \\
Markets & & & 15,21 \\
Asia / Pacific; Asia / Pacific Emerging & 961 & 8,96 & 48,28 \\
Markets & 3.548 & 33,07 & 50,17 \\
Europe; European Developed Markets & 203 & 1,89 & 97,45 \\
Europe; European Emerging Markets & 5.072 & 47,27 & 98,62 \\
United States and Canada & 126 & 1,17 & 100,00 \\
Africa / Middle East & 148 & 1,38 & - \\
Latin America and Caribbean & $\mathbf{1 0 . 7 2 9}$ & $\mathbf{1 0 0 , 0 0}$ & \\
\hline Total & & & \\
\hline
\end{tabular}

According to the information in Table 3, the sector with the highest concentration of firms is manufacturing, accounting for approximately $40 \%$ of the total sample. Second is the service sector, with $18 \%$, followed by transportation, communications, electricity, gas, and health services (the latter with approximately $10 \%$ ). The sectors with the smallest proportion of firms in the sample correspond to: (1) agriculture, forestry, and fishing with $0.43 \%$; (2) the state (public administration) with $0.71 \%$; and (3) trade with $1.37 \%$.

According to Table 4, the average research investment applied by the sample firms was approximately 22 million dollars. In addition to short-term investments and investments in capital good, the average total volume account for more than $\$ 1.1$ billion. The assets of the companies represent an approximate average value of $\$ 7.33$ billion with capital investment of approximately $\$ 400$ million. 
Table 2

Distribution of firms per sector

\begin{tabular}{lcccc}
\hline Sector - SIC Codes & Frequency & Relative frequency (\%) & Cumulative frequency (\%) \\
\hline Division A: Agriculture, Forestry, And & 46 & 0,43 & 0,43 \\
Fishing & 165 & 1,54 & 1,97 \\
Division B: Mining & 1.160 & 10,81 & 12,78 \\
Division C: Construction & 4.262 & 39,72 & 52,50 \\
Division D: Manufacturing & & & \\
Division E: Transportation, & 1.101 & 10,26 & 62,76 \\
Communications, Electric, Gas, And & & & \\
Sanitary Services & 992 & 9,25 & 72,01 \\
Division F: Wholesale Trade & 147 & 1,37 & 73,38 \\
Division G: Retail Trade & 848 & 7,90 & 81,28 \\
Division H: Finance, Insurance, And & 1.932 & 18,01 & 99,29 \\
Real Estate & 76 & 0,71 & 100,00 \\
Division I: Services & $\mathbf{1 0 . 7 2 9}$ & $\mathbf{1 0 0 , 0 0}$ & - \\
Division J: Public Administration & \multicolumn{2}{c}{} \\
\hline Total & & & \\
\hline
\end{tabular}

Table 3

Descriptive statistics of the variables considered in the model

\begin{tabular}{l|c|c|c}
\hline Variáveis & Mean & Standart deviation & Coefficient of variation \\
\hline mkt_cap (U\$\$ Million) & $3.167,86$ & 14996,7700 & 4,7340 \\
asset (U\$\$ Million) & $7.326,23$ & 46070,9700 & 6,2885 \\
R\&D (U\$\$ Million) & 22,00 & 219,5003 & 9,9751 \\
capex (U\$\$ Million) & 402,72 & 2211,1440 & 5,4906 \\
st_inv (U\$ Million) & 733,09 & 8193,6030 & 11,1769 \\
\hline
\end{tabular}

\subsection{Econometric model}

In Table 5, the regressions with fixed effects show the relations of the model considering the impact of the variables on the average of the conditional distribution. The relationships between the variables demonstrate signs that are consistent with those in the literature presented. The intensity of investments in research on assets has a positive sign and a significant parameter in columns (1) and (2). The same pattern is observed in relation to investments in capital good and short-term investments. Regressions in the mean of the conditional distribution indicate larger magnitudes of the parameters for the mediumintensity firms in R\&D, followed by the low-intensity and high-intensity firms.

Regarding the results in Table 6, the estimated parameters point to a heterogeneous relationship between the model variables, which is not properly captured in the previous table. The parameters obtained by the quantile regression technique demonstrate an increasing return of investment in the measure of value along the conditional quantiles. This fact suggests that firms located in the upper tail of the conditional distribution obtain higher returns from the research investments made. This indicates that the factor approximation with the frontier exerts an increasing influence on the "R\&D-market value" relation.

Figures 1, 2, and 3 present this heterogeneous pattern in the sample, signaling that the increase in conditional quantiles reflects significant changes in the model parameters. In the case of investments in $R \& D$, (Figure 1) the increase in quantiles represents an effect approximation with the frontier, increasing the value of the parameters of the variable and corroborating the hypotheses elucidated. Firms with a higher market value (located in the upper quantiles), which are therefore closer to the technological frontier, present greater abortive capacity, increasing the return on investments in research. This pattern is also observed in short-term investments. 
EXTERNALIDADES DEL I\&D, INNOVACIÓN Y MERCADO DE VALORES: EVIDENCIA DE CAPACIDAD DE ABSORCIÓN EN LA GENERACIÓN DE TECNOLOGÍAS LIMPIAS.

Conversely, investments in capital goods have an inverse relationship over the quantiles (Figure 2). This can be represented by the importance of investing in the dynamics of the firm, which loses its "role" as innovation places greater emphasis on the displacement of the border (Aghion and Howitt 2009).

From the $25 \%$ conditional quantile, R\&D investments exceed the average obtained by the fixedeffect model, suggesting that firms that are further away from the border obtain lower returns with the use of resources. This inversion seems to occur with investments in capital goods, indicating that the firms with the highest performance in the distribution of market value are "less favored" with the use of these resources.

Table 4

Results of the econometric model - Intensity of investments in research on assets. Dependent variable: log(QTobin).

\begin{tabular}{|c|c|c|c|}
\hline VARIABLES & $\begin{array}{c}\text { (1) } \\
\text { High-intensity R\&D }\end{array}$ & $\begin{array}{c}\text { (2) } \\
\text { Medium-intensity R\&D }\end{array}$ & $\begin{array}{c}\text { (3) } \\
\text { Low-intensity R\&D }\end{array}$ \\
\hline $\mathrm{R} \& \mathrm{D} /$ asset & $\begin{array}{l}0.290 * * * \\
(0.0374)\end{array}$ & $\begin{array}{c}10.72 * * * \\
(0.920)\end{array}$ & $\begin{array}{c}1.578 \\
(2.388)\end{array}$ \\
\hline capex/asset & $\begin{array}{c}0.442 * * * \\
(0.130)\end{array}$ & $\begin{array}{c}3.207 * * * \\
(0.156)\end{array}$ & $\begin{array}{c}0.00796 * * * \\
(0.000240)\end{array}$ \\
\hline st_inv /asset & $\begin{array}{c}1.872 * * * \\
(0.487)\end{array}$ & $\begin{array}{c}2.547 * * * \\
(0.0779)\end{array}$ & $\begin{array}{c}1.792 * * * \\
(0.226)\end{array}$ \\
\hline Constant & $\begin{array}{c}2.253 * * * \\
(0.686)\end{array}$ & $\begin{array}{l}0.682 * * \\
(0.287)\end{array}$ & $\begin{array}{l}0.864 * * * \\
(0.0492)\end{array}$ \\
\hline $\mathrm{R}^{2}$ & 0.248 & 0.387 & 0.320 \\
\hline $\mathrm{R}^{2}$-Adj & 0.228 & 0.368 & 0.314 \\
\hline Observations (\% Sample) & $86,065(80.78 \%)$ & $18,716(17.57 \%)$ & $1,768(1.66 \%)$ \\
\hline Fixed Effects & - & - & - \\
\hline Country & yes & yes & yes \\
\hline Sector & yes & yes & yes \\
\hline Year & yes & yes & yes \\
\hline F Test Fixed Effects & $5.32 * * *$ & $13.55 * * *$ & $36.06 * * *$ \\
\hline test for heteroskedasticity & - & - & - \\
\hline Chi2 test & $70.43 * * *$ & $0.84 * * *$ & $1218.436^{* * *}$ \\
\hline test for autocorrelation & - & - & - \\
\hline Chi2 test & $155.385 * * *$ & $260.660 * * *$ & $7.46^{* * *}$ \\
\hline
\end{tabular}

Note: Robust standard errors in parentheses.

Legend: *** $p<0.01,{ }^{* *} p<0.05$, * $p<0.1$

Definition by Sector R\&D intensity: This classification takes into account the R\&D intensity (R\&D/Revenue) with High above $5 \%$, Medium between $1 \%$ and $5 \%$ and Low below 1\% (EUROPEAN COMMISSION, 2017). 
Table 6

Results of the econometric model, total sample. Dependent variable: log(Q-Tobin).

\begin{tabular}{|c|c|c|c|c|c|c|}
\hline \multirow{3}{*}{ VARIABLES } & \multirow{3}{*}{$\begin{array}{c}\text { (1) } \\
\text { FE Cluster- } \\
\text { Robust }\end{array}$} & (2) & (3) & (4) & (5) & (6) \\
\hline & & \multicolumn{5}{|c|}{ Quantile Regression Cluster-Robust } \\
\hline & & $10 \%$ & $25 \%$ & $50 \%$ & $75 \%$ & $90 \%$ \\
\hline $\mathrm{R} \& \mathrm{D} / \mathrm{asset}$ & $\begin{array}{l}0.139 * * \\
(0.0526)\end{array}$ & $\begin{array}{c}0.0538 * * * \\
(0.00111)\end{array}$ & $\begin{array}{c}0.125 * * * \\
(0.0175)\end{array}$ & $\begin{array}{c}0.508 * * * \\
(0.0558)\end{array}$ & $\begin{array}{c}1.107 * * * \\
(0.131)\end{array}$ & $\begin{array}{c}1.285^{* * *} \\
(0.101)\end{array}$ \\
\hline \multirow[t]{2}{*}{ capex/asset } & $0.00858 * * *$ & $0.00897 * * *$ & $0.00849 * * *$ & $0.00788 * * *$ & $0.00712 * * *$ & $0.00662 * * *$ \\
\hline & $(0.000863)$ & $(0.000261)$ & $(0.000175)$ & $(0.000102)$ & $(0.000126)$ & $(0.000266)$ \\
\hline \multirow[t]{2}{*}{ st_inv /asset } & $2.226 * * *$ & $1.796^{* * *}$ & $1.863 * * *$ & $1.976^{* * *}$ & $2.127 * * *$ & $2.492 * * *$ \\
\hline & $(0.111)$ & $(0.127)$ & $(0.0341)$ & $(0.105)$ & $(0.120)$ & $(0.155)$ \\
\hline \multirow[t]{2}{*}{ Constant } & $0.864 * * *$ & $0.385 * * *$ & $0.458 * * *$ & $0.770 * * *$ & $0.916^{* * *}$ & $0.952 * * *$ \\
\hline & $(0.0306)$ & $(0.118)$ & $(0.146)$ & & $(0.0489)$ & $(0.113)$ \\
\hline Fixed Effects & - & - & - & - & - & - \\
\hline Country & yes & yes & yes & yes & yes & yes \\
\hline Sector & yes & yes & yes & yes & yes & yes \\
\hline Year & yes & yes & yes & yes & yes & yes \\
\hline $\begin{array}{l}\text { F Test Fixed } \\
\text { Effects }\end{array}$ & $20.38 * * *$ & $5365.72 * * *$ & $143.60 * * *$ & $114.00 * * *$ & $80.58 * * *$ & $13.76 * * *$ \\
\hline [Pseudo]-R ${ }^{2}$ & 0.308 & 0.248 & 0.288 & 0.241 & 0.145 & 0.149 \\
\hline
\end{tabular}

Note: Robust standard errors in parentheses.

Legend: ${ }^{* *} p<0.01,{ }^{* *} p<0.05,{ }^{*} p<0.1$

Figure 1

Quantile regression estimates - R\&D /asset coefficients.

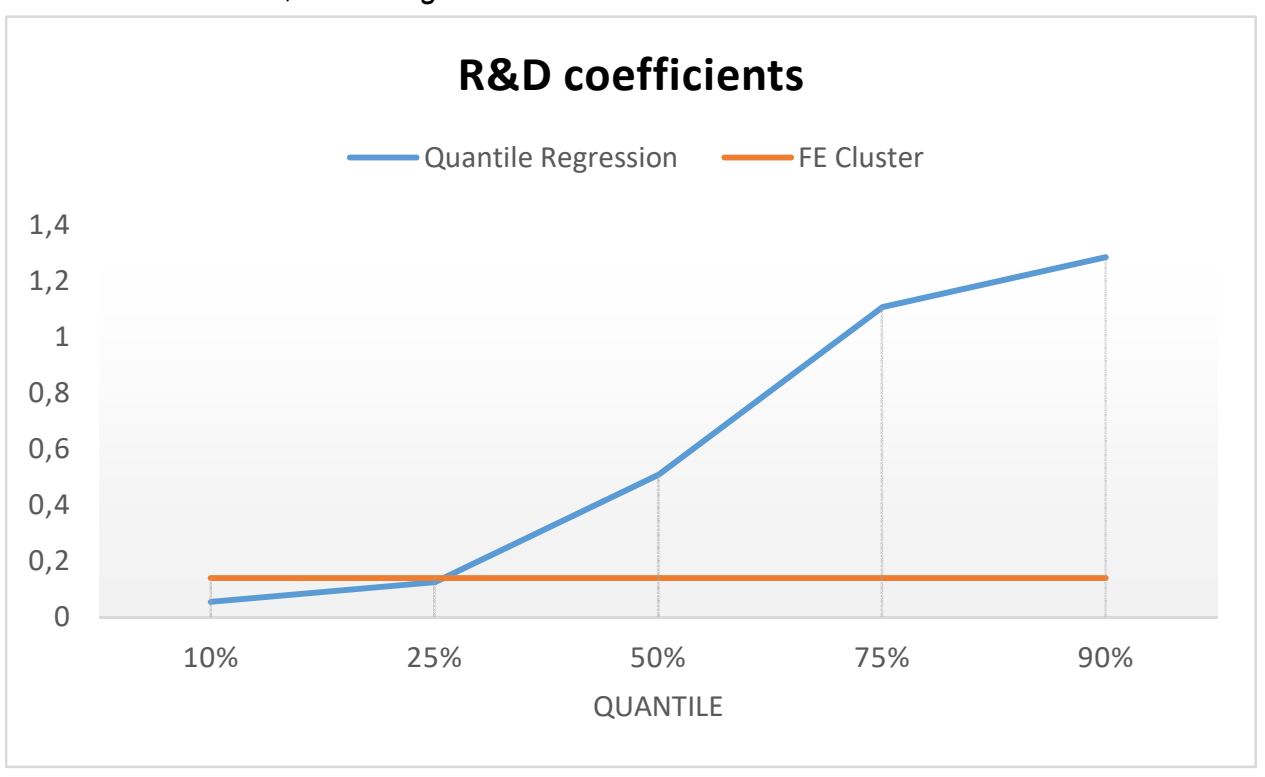


EXTERNALIDADES DEL I\&D, INNOVACIÓN Y MERCADO DE VALORES: EVIDENCIA DE CAPACIDAD DE ABSORCIÓN EN LA GENERACIÓN DE TECNOLOGÍAS LIMPIAS.

Figure 2

Quantile regression estimates - capex /asset coefficients.

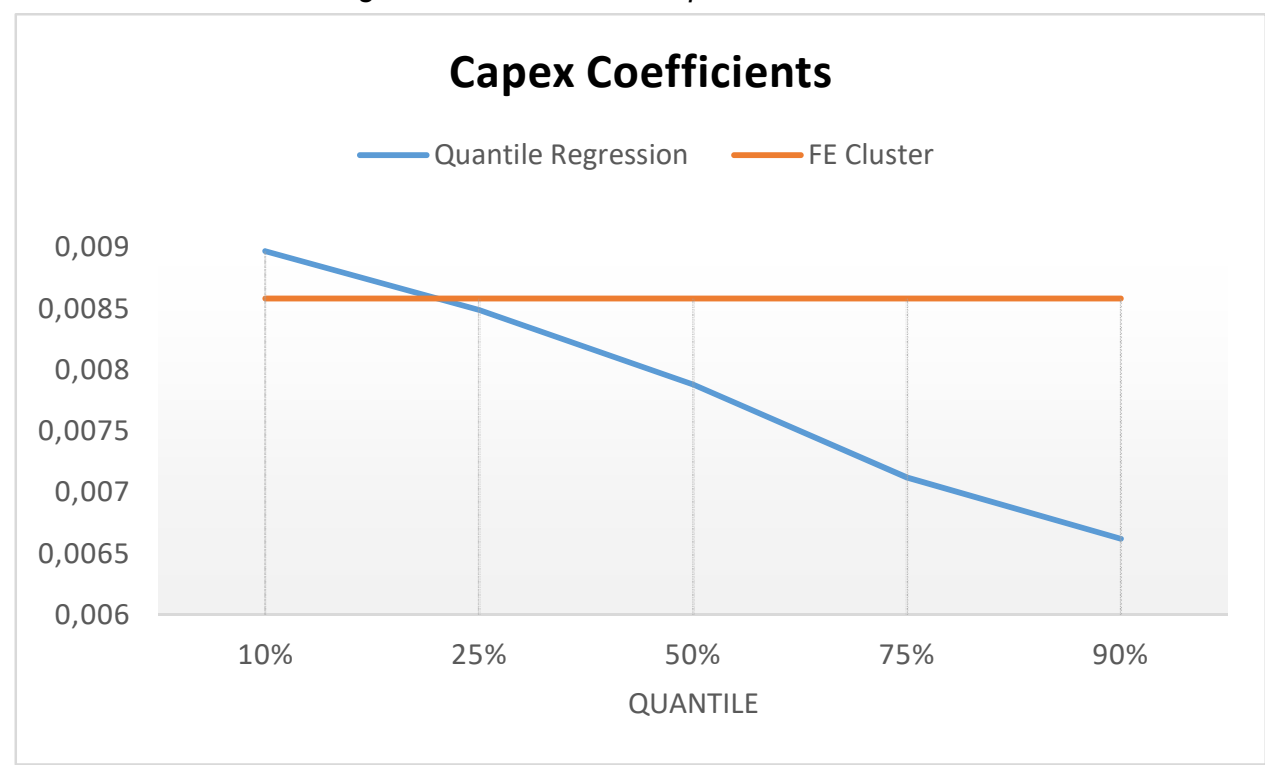

Comparing the parameters between the quantiles, the firms located in the upper tail of the distribution ( $90 \%$ quantile) present an impact measure of the $\mathrm{R} \& \mathrm{D} /$ Assets equivalent to more than 23 times the value of the firms in the $10 \%$ quantile. This difference diminishes when compared with the short-term investments in such a way that firms closer to the border (90\% quantiles) show a better return with the use of these investments that is 1.39 times more than that of the firms in the $10 \%$ quantile (Figure 3 ).

Figure 3

Quantile regression estimates - st_inv /asset coefficients.

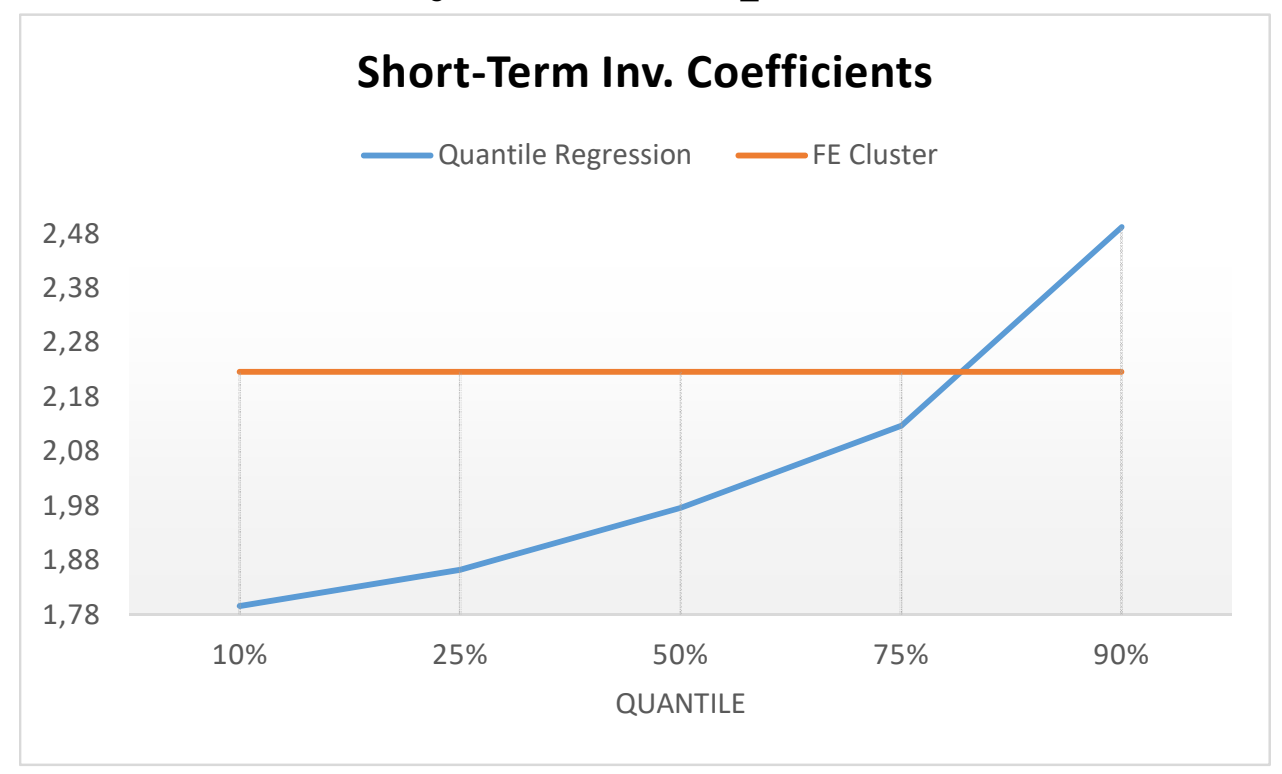

\subsection{Discussion of the results}

The results presented suggest that the return on investment in R\&D shows a heterogeneous character in the sample, reflecting the presence of absorptive capacity in resource performance. Such aspects have been evidenced in other studies, contemplating different techniques and samples.

Griffith, Redding, and Reenen (2003) determined that the close sectors of the technological frontier show higher returns on R\&D investments in terms of productivity increases. Controlling the effect of absorptive capacity, the direct effect of investments on productivity gains presents nearly a $40 \%$ 
difference in estimates. The results are consistent with similar research on the subject (Griffith, Redding, and Reenen 2004; Kneller and Stevens 2006; Kolk 2015; Flor, Cooper, and Oltra 2018; Rocha et al. 2018).

In addition, Aghion and Jaravel (2015) showed that such (clean) technologies naturally constitute barriers between firms and countries. These stem from less developed nations' need for structural investments in their own technological capabilities, encouraging local firms to invest in the R\&D needed to adopt the "clean" technologies derived from developed economies.

However, other research has shown that the absorptive capacity can contribute to increasing the costs associated with such gains, nullifying their potential effects (Lichtenthaler 2016). Such divergence points to the need for further study on the subject.

Although the results are consistent with the recent literature, some limitations need to be better addressed. Problems associated with endogeneity may hinder part of the inference in the model, since cause-effect relationships are not adequately controlled. Although the quantum technique presents a more precise picture of the relations, from the different points of the conditional distribution of the dependent variable, factors conditioning the demand for investments in R \& D (AGHION \& HOWITT, 2009) or even measurement errors in the independent variable (RACICOT, 2015) limit the inference of estimates, since they are more present in financial series (RACICOT \& RENTZ, 2018). Racicot (2015) and Racicot and Rentz $(2015,2016$ and 2018) illustrate an important discussion on this topic, proposing alternative estimators to the traditional GMM, more robust to the presence of measurement errors. Future research may venture into alternative techniques in order to corroborate or refute the questions raised through here.

\section{CONCLUSIONS}

The results of the research suggest an important heterogeneous relationship between innovation and firm performance. By means of recent advances in the quantile regression technique, $R \& D$ investments show a greater contribution to the value of firms located on the technological frontier. This signals differentiated incentives in firms that generate clean technologies, pointing out the effects of absorptive capacity that leverage the results of research investments.

Regarding the environmental issue, this understanding is important, given that the focus of the global policy is on determining how less developed nations can absorb the clean technologies generated by more developed nations and how to encourage this pattern of innovation in a sustainable way. For this, it is important to understand that the diffusion of clean technologies among nations does not consist a "free lunch" (Aghion and Jaravel 2015).

These aspects are reflected in differentiated performance relationships among firms/sectors/countries, implying heterogeneous results and, possibly, favoring more developed segments. Such implications may highlight the potential costs involved in technology transfer, as innovation efforts generate limited results, especially for firms with poor performance.

\section{BIBLIOGRAPHY REFERENCES}

ACEMOGLU, D., AGHION, P., \& ZILIBOTTI, F. (2006). Distance to Frontier, Selection and Economic Growth. Journal of the European Economic Association, 4(1), 37-74.

ACEMOGLU, D., AGHION, P., BURSZTYN, B., \& HEMOUS, D. (2012). The Enviromental and Directed Technical Change. American Economic Review, 102(1), págs. 131-166.

ACEMOGLU, D., AGHION, P., BURSZTYN, B., \& HEMOUS, D. (2012). The Enviromental and Directed Technical Change. American Economic Review, 102(1), 131-166.

ACEMOGLU, D., AKCIGIT, U., HANLEY, D., \& KERR, W. (2016). Transition to Clean Technology. Journal of Political Economy, 124(1), págs. 52-104.

ACEMOGLU, D., AKCIGIT, U., HANLEY, D., \& KERR, W. (2016). Transition to Clean Technology. Journal of Political Economy, 124(1), 52-104.

AGHION, P., \& HOWITT, P. (1998). Endogenous Growth Theory. Cambridge, MA: MIT Press.

AGHION, P., \& HOWITT, P. (2009). The Economics of Growth. Cambridge, Massachusetts: The MIT Press.

AGHION, P., \& JARAVEL, X. (2015). Knowledge Spillovers, Innovation and Growth . The Economic Journal, 125(583), 533-545. 
EXTERNALIDADES DEL I\&D, INNOVACIÓN Y MERCADO DE VALORES: EVIDENCIA DE CAPACIDAD DE ABSORCIÓN EN LA GENERACIÓN DE TECNOLOGÍAS LIMPIAS.

AMABLE, B., DEMMOU, L., \& LEDEZMA, I. (2010). Product market regulation, innovation and distance to frontier. Industrial and Corporate Change, 19(1), 117-159.

ARBUSSÀ, A., \& COENDERS, G. (2007). Innovation activities, use of appropriation instruments and absorptive capacity: Evidence from Spanish firms. Research Policy, 36(10), 1545-1558.

ARROW, K. (1962). Economic welfare and the allocation of resources for invention. En R. NELSON (Ed.), The Rate and Direction of Inventive Activity. Princeton: Princeton University Press.

BELENZON, S. (2012). Cumulative Innovation and Market Value: Evidence from Patent Citations. The Economic Journal, 122(559), 265-285.

BESTER, C., \& HANSEN, C. (2016). Grouped effects estimators in fixed effects models. Journal of Econometrics, 190(1), 197-208.

BLOOM, N., \& REENEN, J. (2002). Patents, Real Options and Firm Performance. The Economic Journal, 112(478), C97-C116.

BOGLIACINO, F., \& CORDONA, S. (2010). The determinants of R\&D Investment: the role of Cash flow and Capabilities. Working Paper (No. 10/2010), European Commission's Joint Research Centre (JRC). Fonte: Industrial Research Monitoring and Analysis (IRMA), European Commission's Joint Research Centre (JRC): http://iri.jrc.es/

BOURKE, J., \& ROPER, S. (2017). Innovation, quality management and learning: Short-term and longer-term effects. Research Policy, Forthcoming.

CANAY, I. (2011). A simple approach to quantile regression for panel data. Econometric Journal, 14(3), 368-396.

CASTELLANI, D., MONTRESOR, S., SCHUBERT, T., \& VEZZANI, A. (2017). Multinationality, R\&D and productivity: Evidence from the top R\&D investors worldwide. International Business Review, 26(3), 405416.

COAD, A. (2008). Distance to Frontier and Appropriate Business Strategy. Papers on Economics and Evolution 2008-07, Max Planck Institute of Economics, Evolutionary Economics Group.

COAD, A. (2011). Appropriate business strategy for leaders and laggards. Industrial and Corporate Change, 20(4), 1049-1079.

COAD, A., \& RAO, R. (2006). Innovation and market value: A quantile regression analysis. Economics Bulletin, 15(13), 1-10.

COCKBUNR, I., \& HENDERSON, R. (1998). Absorptive Capacity, Coauthoring Behavior, and the Organization of Research in Drug Discovery. Journal of Industrial Economics, 46(2), 157-182.

COCKBURN, I., \& GRILICHES, Z. (1988). Industry Effects and Appropriability Measures in the Stock Market's Valuation of R\&D and Patents. American Economic Review, 78(2), 419-423.

CREMERS, M., PAREEK, A., \& SAUTNER, Z. (2017). Short-Term Investors, Long-Term Investments, and Firm Value. Recuperado el 15 de 05 de 2017, de SSRN: https://ssrn.com/abstract=2720248

DEMIRAG, I. (1996). The impact of managers' short-term perceptions on technology management and r\&d in uk companies. Technology Analysis \& Strategic Management , 8(1), 21-32.

DIAS, A. (2013). Market capitalization and Value-at-Risk. Journal of Banking \& Finance, 37(12), 5248-5260.

DING, S., SUN, P., \& JIANG, W. (2016). The Effect of Import Competition on Firm Productivity and Innovation: Does the Distance to Technology Frontier Matter? Oxford Bulletin of Economics and Statistics, 78(2), 0305-9049.

EUROPEAN COMMISSION. (2017). The 2017 EU Industrial R\&D Investment Scoreboard. EU R\&D Scoreboard. Luxembourg: Publications Office of the European Union. Obtenido de Publications Office of the European Union: http://ipts.jrc.ec.europa.eu/

FLOR, M., COOPER, S., \& OLTRA, M. (2018). External knowledge search, absorptive capacity and radical innovation in high-technology firms. European Management Journal, 36(2), 183-194.

GLUCH, P., GUSTAFSSON, M., \& THUVANDER, L. (2009). An absorptive capacity model for green innovation and performance in the construction industry. Construction Management and Economics, 27(5), 451-464.

GRIFFITH, R., REDDING, S., \& VAN REENEN, J. (2003). R\&D and absorptive capacity: theory and empirical evidence. Scandinavian Journal of Economics, 105(1), 99-118.

GRIFFITH, R., REDDING, S., \& VAN REENEN, J. (2004). Mapping the two faces of R\&D: Productivity growth in a panel of OECD industries. Review of Economics and Statistics, 86(4), 883-895.

GUPTA, K., BANERJEE, R., \& ONUR, I. (2017). The effects of R\&D and competition on firm value: International evidence. International Review of Economics \& Finance, 51, 391-404.

HALL, B. (1993). The stock market's valuation of R\&D investment during the 1980's. American Economic Review, 83, págs. 259-264.

HALL, B. (2000). Innovation and market value. In R. BARRELL, G. MASON, \& M. O'MAHONEY (Eds.), Productivity, Innovation and Economic Performance (pp. 177-198). Cambridge: Cambridge University Press.

HALL, B. (2002). The Financing of Research and Development. Oxford Review of Economic, 18(1), 35-51.

HALL, B., \& ORIANI, R. (2006). Does the market value R\&D investment by European firms? Evidence from a panel of manufacturing firms in France, Germany, and Italy. International Journal of Industrial Organization, 24(5), págs. 971- 993.

HALL, B., JAFFE, A., \& TRAJTENBERG, M. (2005). Market Value and Patent Citations. The RAND Journal of Economics, 36(1), 16-38.

HALL, B., LOTTI, F., \& MAIRESSE, J. (2008). Employment, innovation, and productivity: evidence from Italian microdata. Industrial and Corporate Change, 17(8), 813-839. 
HALL, B., LOTTI, F., \& MAIRESSE, J. (2013). Evidence on the impact of R\&D and ICT investments on innovation and productivity in Italian firms. Economics of Innovation and New Technology, 22(3), 300-328.

HALL, B., MAIRESSE, J., \& MOHNEN, P. (2010). Measuring the Returns to R\&D. En B. HALL, \& N. ROSENBERG, Handbook of the Economics of Innovation (Vol. 2, págs. 1033-1082). Amsterdan: North-Holland by Elsevier.

HÖLZL, W., \& JANGER, J. (2014). Distance to the frontier and the perception of innovation barriers across European countries. Research Policy, 43, 707-725.

KANCS, d., \& SILIVERSTOVS, B. (2016). R\&D and non-linear productivity growth. Research Policy, 45(6), 634646.

KNELLER, R., \& STEVENS, P. (2006). Frontier Technology and Absorptive Capacity: Evidence from OECD Manufacturing Industries. Oxford Bulletin of Economics \& Statistics, 68(1), 1-21.

KOLK, A. (2015). The role of international business in clean technology transfer and development. Climate Policy, 15(1), 170-176.

LICHTENTHALER, U. (2016). Absorptive capacity and firm performance: an integrative framework of benefits and downsides. Technology Analysis \& Strategic Management, 28(6), 664-676.

MONTRESOR, S., \& VEZZANI, A. (2015). On the R\&D giants' shoulders: Do FDI help to stand on them? Journal of Industrial and Business Economics, 42(1), 33-60.

MUSCIO, A. (2007). The Impact of Absorptive Capacity on SMEs' Collaboration. Economics of Innovation and New Technology, 16(8), 653-668.

NELSON, R. (1959). The simple economics of basic research. Journal of Political Economy, 67, 297-306.

POPP, D. (2011). International Technology Transfer, Climate Change, and the Clean Development Mechanism. Review of Environmental Economics and Policy, 5(1), 131-152.

RACICOT, F. (2015). Engineering robust instruments for panel data regression models with errors in variables: $\mathrm{A}$ note. Applied Economics, 47, 981-989.

RACICOT, F., \& RENTZ, W. (2015). The Pástor-Stambaugh empirical model revisited: Evidence from robust instruments. Journal of Asset Management, 16(5), 329-341.

RACICOT, F., \& RENTZ, W. (2016). Testing Fama-French's new five-factor asset pricing model: Evidence from robust Instrumental variables. Applied Economics Letters, 23(6), 444-448.

RACICOT, F., \& RENTZ, W. (2018). Does Illiquidity Matter? An Errors-in-Variables Perspective. Estudios de Economía Aplicada, 36(1), 251 - 262.

ROCHA, L., CARDENAS, L., LOPES, F., OLIVEIRA, F., \& FERNANDES, K. (2018). The Impact of R\&D Investments on Performance of Firms in Different Degrees of Proximity to the Technological Frontier. Economics Bulletin, 38(2), 1156-1170.

YENCKEN, J., \& GILLIN, M. (2003). Public research agencies as sources for innovations and the entrepreneurial absorptive capacity of manufacturing enterprises. Innovation: Organization \& Management, 5(1), 29-39. 